\title{
Synthesis and Characterization of a Water Stable Uranyl(V) Complex
}

\author{
Radmila Faizova, Rosario Scopelliti, Anne-Sophie Chauvin, and Marinella Mazzanti*(i) \\ Institut des Sciences et Ingénierie Chimiques, Ecole Polytechnique Fédérale de Lausanne (EPFL), CH-1015 Lausanne, Switzerland
}

Supporting Information

ABSTRACT: We have identified a polydentate aminocarboxylate ligand that stabilizes uranyl(V) in water. The mononuclear $\left[\mathrm{UO}_{2}(\right.$ dpaea $\left.)\right] \mathrm{X},\left(\right.$ dpaeaH $_{2}=\mathrm{Bis}$ (pyridyl-6methyl-2-carboxylate)-ethylamine; $\mathrm{X}=\mathrm{CoCp}_{2}{ }^{*+}$ or $\mathrm{X}=$ $\mathrm{K}(2.2 .2$.cryptand) complexes have been isolated from anaerobic organic solution, crystallographically and spectroscopically characterized both in water and organic solution. These complexes disproportionate at $\mathrm{pH} \leq 6$, but are stable in anaerobic water at $\mathrm{pH} 7-10$ for several days.

$I^{n}$ $\mathrm{n}$ recent years, an increasing number of molecular complexes containing actinides in rare and unstable oxidation states have been isolated by using appropriate supporting ligands, ${ }^{1}$ but ligands capable of stabilizing $\mathrm{U}(\mathrm{V})$ in water remain an unmet target. $\operatorname{Uranyl}(\mathrm{V})\left(\mathrm{UO}_{2}{ }^{+}\right)$is reported to have a very limited range of stability in aqueous solution where it disproportionates to the more stable uranyl(VI) and uranium(IV) aqua species. ${ }^{2}$ However, in the past decade the importance of uranyl(V) species in aqueous uranium chemistry associated with environmental, geologic and nuclear technology applications has become increasingly more evident. ${ }^{1 \mathrm{e}, 3}$ Notably, there has been an increasing number of reports documenting the occurrence of $\mathrm{U}(\mathrm{V})$ during the mineral mediated and microbial reduction of soluble uranyl(VI) species to insoluble U(IV) ones. ${ }^{3 c, d, 4}$ Despite the importance of these processes for the removal from the groundwater of uranium, occurring from mining or disposal of radioactive waste, the role of $\mathrm{U}(\mathrm{V})$ remains unclear due the low stability of this species in aqueous media and the lack of appropriate synthetic models.

So far, studies of aqueous uranyl(V) chemistry are limited to the aqua ion at low $\mathrm{pH}(2-4)$ where disproportionation is slow ${ }^{5}$ and to the carbonate complex $\left[\mathrm{UO}_{2}\left(\mathrm{CO}_{3}\right)_{3}\right]^{4-6}$ produced by electrochemical reduction of the uranyl(VI) analogue in concentrated carbonate solutions that were stable in a narrow $\mathrm{pH}$ range $(11.7-12)$ over a period of at least $2 \mathrm{~h}$, but never isolated.

The first example of a uranyl(V) complex that could be reproducibly isolated was prepared in nonaqueous media more than ten years ago. ${ }^{1 f, 7}$ Driven by this report, the chemistry of uranyl(V) in nonprotic media has experienced a significant expansion. ${ }^{1 \mathrm{e}, 3 \mathrm{~b}, 8}$ Monometallic and polymetallic complexes of uranyl $(V)$ that are stable in organic solvents have been isolated using bulky polydentate supporting ligands. Several of these complexes have shown interesting magnetic properties and reactivity, but none of these complexes is stable in water solution. ${ }^{3 g, 9}$ Hence, in spite of the significant development of uranyl $(\mathrm{V})$ chemistry in the past decade, very little is still known about the chemistry of this species in water. The isolation of a $\mathrm{U}(\mathrm{V})$ complex that is stable in water, at environmentally relevant $\mathrm{pH}$, has been a long sought-after goal because it would provide a valuable tool for the study of stability and reactivity of this species in environmental media, but the low charge of the uranyl $(\mathrm{V})$ cation and its tendency to disproportionate renders the formation of stable complexes difficult.

Here we report the synthesis in anaerobic organic solution and the characterization both in organic and water solution of a uranyl(V) complex that shows high stability in anaerobic water. The aminocarboxylate ligand $\mathrm{dpaea}^{2-}\left(\mathrm{dpaeaH}_{2}=\right.$ bis(pyridyl-6-methyl-2-carboxylate)-ethylamine) combining the pentadentate binding mode and the ability to form stable complexes with metal cations in water, ${ }^{10}$ is revealed to be perfectly suited to stabilize the uranyl(V) cation in anaerobic water in the $\mathrm{pH}$ range 7-10. Notably, the pentadentate coordination stabilizes uranyl(V) with respect to disproportionation through electronic and steric effects, ${ }^{8 e}$ while the presence of the carboxylate groups prevents ligand dissociation in water solution.

The uranyl(VI) complex $\left[\mathrm{UO}_{2}(\right.$ dpaea $\left.)\right]$ (1) was prepared from the reaction of $\left[\mathrm{UO}_{2}\left(\mathrm{NO}_{3}\right)_{2}\left(\mathrm{H}_{2} \mathrm{O}\right)_{6}\right]$ with $\mathrm{H}_{2}$ dpaea in methanol in the presence of a base. The uranyl $(\mathrm{V})$ complexes $\left[\mathrm{UO}_{2}(\right.$ dpaea $\left.)\right] \mathrm{X}, 2,\left(\mathrm{X}=\mathrm{CoCp}_{2}{ }^{*+}\right)$ and $3,(\mathrm{X}=\mathrm{K}-$ (2.2.2.cryptand) were prepared in pyridine solution in 68$79 \%$ yield, both by reduction of the uranyl(VI) analogue 1 and by the reaction of the uranyl $(\mathrm{V})$ iodide precursor $\left[\left(\mathrm{U}^{\mathrm{V}} \mathrm{O}_{2} \mathrm{Py}_{5}\right)\right.$ $\left.\left(\mathrm{KI}_{2} \mathrm{P}_{2}\right)\right]_{n}{ }^{1 f}$ with $\mathrm{K}_{2}$ dpaea (Scheme 1) under argon. Single crystals of the uranyl(VI) complex $\left[\mathrm{UO}_{2}(\right.$ dpaea $\left.)\left(\mathrm{D}_{2} \mathrm{O}\right)\right]$ (4) were obtained by exposing a solution of 3 in deuterated water to air.

The solid-state structures of the complexes 1, 2, 3 and 4 were determined by X-ray diffraction studies (Figure 1 and Figures S32-S36). The molecular structure of 1 shows the presence of a uranium(VI) cation heptacoordinated, with a

Scheme 1. Synthesis of 2 and 3
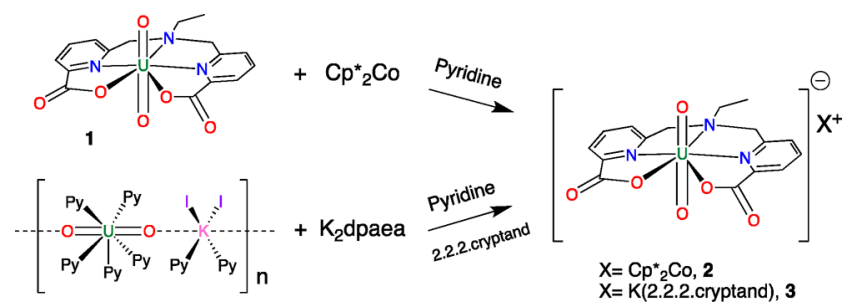

Received: July 25, 2018

Published: October 5, 2018 


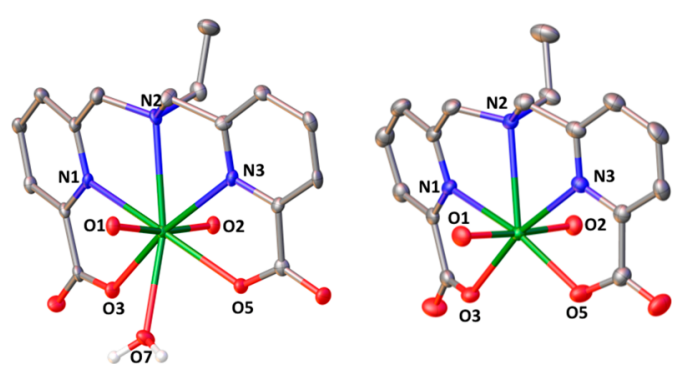

Figure 1. Ellipsoid plot at $50 \%$ probability of complex $\left[\mathrm{UO}_{2}(\right.$ dpaea $\left.)\left(\mathrm{D}_{2} \mathrm{O}\right)\right], 4$ and of the anion $\left[\mathrm{UO}_{2}(\text { dpaea })\right]^{-}$in 3 (cocrystallized pyridine and water molecule along with hydrogen atoms were omitted for clarity, $\mathrm{C}$ are represented in gray, $\mathrm{O}$ in red, $\mathrm{N}$ in blue and $U$ in green).

slightly distorted pentagonal bipyramid geometry, by the three nitrogen and two oxygen atoms of the dianionic pentadentate ligand $\mathrm{dpaea}^{2-}$ in the equatorial plane and by two oxo groups in axial position with values of the $\mathrm{U}=\mathrm{O}$ bond distances of 1.75(3) ^̊.

The arrangement of the ligand is perfectly planar for the complex 1 , while the coordination of water in 4 results in a slight deviation from planarity (mean deviation $=0.0894 \AA)$. In the structure of complex 4 , the $U(V I)$ is eight-coordinated by the dpaea ${ }^{2-}$ ligand and one water molecule in the equatorial plane and by two oxo groups in axial position with a mean value of the $\mathrm{U}=\mathrm{O}$ bond distances of $1.778(4) \AA$ similar to those found in $\mathbf{1}$. The $\mathrm{U}-\mathrm{O}$ bond distance of the bound water molecule is longer (2.572(4) A) than what found in 7coordinate uranyl(VI) Schiff base complexes $(2.430(5) \AA) .{ }^{11}$ Interestingly, the $\mathrm{O}=\mathrm{U}=\mathrm{O}$ bond in $\mathbf{4}$ deviates significantly from the usually linear arrangement $(\mathrm{O} 1-\mathrm{U} 1-\mathrm{O} 2=$ $170.7(2)^{\circ}$ ) of the $\mathrm{UO}_{2}{ }^{2+}$ group probably due to steric repulsion. ${ }^{12}$ This deviation is somewhat related to the water binding since a larger angle is found in $\mathbf{1}$ (O1- $\mathrm{U} 1-$ $\left.\mathrm{O} 1 *=176.9(7)^{\circ}\right)$.

The molecular structures of $\mathbf{2}$ (Figures S34) and $\mathbf{3}$ (Figures 1 and S35) show the presence of ion pairs and only differ in the nature of the counterion $\left(\left[\mathrm{CoCp}_{2} *\right]^{+}\right.$in 2 and $[\mathrm{K}(2.2 .2 \text {.cryptand })]^{+}$) in 3 . The structure of the $\left[\mathrm{UO}_{2}(\mathrm{dpaea})\right]^{-}$anion is very similar in $\mathbf{2}$ and $\mathbf{3}$ and shows the presence of a uranium $(\mathrm{V})$ cation heptacoordinated, with a pentagonal bipyramidal geometry, by two trans oxo groups and by the five coplanar $\mathrm{O} 2 \mathrm{~N} 3$ donor atoms of the dpaea ${ }^{2-}$ ligand (with a mean deviation of $0.0304 \AA$ ). Thus, the dpaea ${ }^{2-}$ ligand reveals itself to be perfectly adapted to tightly bind the uranyl(V) cation and therefore to stabilize this species in protic solvents. ${ }^{13}$ The $\mathrm{O}=\mathrm{U}=\mathrm{O}$ angle is $177.0(6)^{\circ}$ and $176.06(8)^{\circ}$ for 2 and 3 respectively. The $\mathrm{U}=\mathrm{O}$ bond distances in 2 and 3 (1.84(1) §) are significantly longer compared to $\mathbf{1}$ and $\mathbf{4}$, which is in agreement with the presence of a reduced uranium center. These values are analogous to those reported for other crystallographically characterized heptacoordinated uranyl(V) complexes. $^{8 \mathrm{e}}$ The infrared spectra of $\mathbf{2}$ and $\mathbf{3}$ as $\mathrm{KBr}$ pellets show strong bands at 787 and $794 \mathrm{~cm}^{-1}$ respectively, which were assigned to the asymmetric $\mathrm{UO}_{2}{ }^{+}$stretching mode. These values are lower compared to the hexavalent $\left[\mathrm{UO}_{2}(\mathrm{dpaea})\right]$ species $\left(913 \mathrm{~cm}^{-1}\right)$ in agreement with a weaker $\mathrm{U}-\mathrm{O}$ bond due to the increased electronic repulsion between the reduced uranium center and the oxygen atom. A similar difference was observed between $\left[\left(\mathrm{U}^{\mathrm{V}} \mathrm{O}_{2} \mathrm{Py}_{5}\right)\left(\mathrm{KI}_{2} \mathrm{Py}_{2}\right)\right]_{n}\left(797 \mathrm{~cm}^{-1}\right)$ and $\left.\left[\mathrm{U}^{\mathrm{VI}} \mathrm{O}_{2} \mathrm{I}_{2} \mathrm{Py}_{3}\right)\right]\left(927 \mathrm{~cm}^{-1}\right){ }^{1 \mathrm{f}}$
Both uranyl(V) complexes were shown, by ${ }^{1} \mathrm{H}$ NMR spectroscopy, to be stable in nonprotic solvents (pyridine, acetonitrile and DMSO) up to 4 months (Figures S3 and S7). On addition of 1 equiv PyHOTf to 3 in DMSO, an immediate disproportionation reaction was observed as indicated by the complete disappearance of the ${ }^{1} \mathrm{H}$ NMR signals assigned to 3 and the appearance of the signals assigned to the U(IV) complex $\left[\mathrm{U}(\text { dpaea })_{2}\right], 5$ and $\mathrm{H}_{2} \mathrm{O}$. Single crystals of the poorly soluble $\left[\mathrm{UO}_{2}(\right.$ dpaea $\left.)\right]$ were also isolated from the disproportionation mixture and characterized by XRD. The complex 5 was independently prepared from the reaction of $\mathrm{UI}_{4}$ and 2 equiv of $\mathrm{K}_{2}$ dpaea and crystallographically characterized (Figure S36). These results indicated that the monomeric uranyl (V) complex undergoes disproportionation upon protonation of the uranyl oxo groups as suggested by previous computational studies. $^{14}$

However, once isolated the complexes 2 and 3 can be dissolved in water affording yellow and pink solutions, respectively, of uranyl(V) complexes. These complexes are stable, with respect to ligand dissociation and disproportionation, as indicated by ${ }^{1} \mathrm{H}$ NMR studies in $\mathrm{D}_{2} \mathrm{O}$ (Figures $\mathrm{S} 4$ and S6). Notably, the ${ }^{1} \mathrm{H}$ NMR spectrum of 2 and 3 in $1-15 \mathrm{mM}$ $\mathrm{D}_{2} \mathrm{O}$ solutions shows after dissolution the presence of only one set of 7 signals with chemical shifts similar to those found in $\mathrm{C}_{5} \mathrm{D}_{5} \mathrm{~N}$ solution, suggesting the presence of analogous rigid $\mathrm{C}_{2}$ symmetric species in both solvents. The value of the $\mathrm{pH}$ measured for water solutions of 3 at various concentrations $(1-15 \mathrm{mM})$ ranges from 9.2 to $10 .{ }^{1} \mathrm{H}$ NMR studies of $7-15$ $\mathrm{mM} \mathrm{D}_{2} \mathrm{O}$ solutions of 3 over time indicate that the complex is stable in these conditions up to 2 weeks and then the amount of complex in solution slowly decreases (Figures S11-13). After 5 weeks and up to 3 months, $50 \%$ of 2 and 3 were still present in $\mathrm{D}_{2} \mathrm{O}$ solution. The half-life of the complex increases with decreasing concentration suggesting that dimer formation may be involved in the disproportionation of the protonated species. The ${ }^{1} \mathrm{H}$ NMR spectrum of a $16 \mathrm{mM} \mathrm{D}_{2} \mathrm{O}$ solution of 3 at $\mathrm{pH}=7$ (adjusted with $\mathrm{DCl}$ ) also showed the presence of a fully stable uranyl(V) complex that remained unchanged at least for 3 days. Small amounts of disproportionation products $\left(\left[\mathrm{U}(\text { dpaea })_{2}\right]\right)$ start to appear after 5 days. ${ }^{1} \mathrm{H}$ NMR studies of a $20 \mathrm{mM} \mathrm{D} \mathrm{D}_{2} \mathrm{O}$ solution of 3 at $\mathrm{pH}=6$ showed that more than $80 \%$ of the complex 3 had undergone disproportionation after 2 days (Figure S17).

These experiments indicated that acid-induced disproportionation of the uranyl(V) dpaea complex occurs rapidly in organic solution in the presence of stoichiometric amounts of proton. Moreover, the $\left[\mathrm{UO}_{2}(\text { dpaea })\right]^{-}$complex is stable toward disproportionation in water solution in the $\mathrm{pH}$ range 10-7 for several days. These results demonstrate that uranyl $(\mathrm{V})$ can be stabilized by aminocarboxylate ligands in environmental conditions. Moreover, the protonation studies indicate that protonation is most likely the first step in the disproportionation mechanism of such mononuclear complexes as suggested by DFT studies. ${ }^{14 c}$

The room temperature magnetic moment of 3 was determined both in pyridine $\left(\mu_{\text {eff }}=2.1 \mu_{\mathrm{B}}\right)$ and $\mathrm{D}_{2} \mathrm{O}\left(\mu_{\text {eff }}=\right.$ $\left.2.2 \mu_{\mathrm{B}}\right)$ solutions at $\mathrm{pH}=10$ by ${ }^{1} \mathrm{H}$ NMR spectroscopy using the Evans method. ${ }^{15}$ The measured value is consistent with the presence of one $5 f^{1}$ uranyl(V) center and is the same in both solvents confirming the stability of $\mathbf{3}$ in water solution (Figures S25 and S26). X-Band EPR spectra of 3 were recorded both in solid state and in $\mathrm{D}_{2} \mathrm{O}$ solution $(25 \mathrm{mM})$ at $10 \mathrm{~K}$. In both cases, the spectra could be fitted with a rhombic set of $g$ values: 
$g_{1}=3.04 ; g_{2}=1.08 ; g_{3}<0.6$ for solid state and $g_{1}=2.59 ; g_{2}=$ $1.21 ; g_{3}<0.6$ for the $\mathrm{D}_{2} \mathrm{O}$ solution (Figures $\mathrm{S} 30$ and $\mathrm{S} 31$ ). The measured EPR data confirm the presence of uranyl(V) species in water solution.

Cyclic voltammetry studies of complex 3 were carried out both in pyridine and $\mathrm{H}_{2} \mathrm{O}$ solutions, but studies of 1 were prevented by its low solubility. The cyclic voltammetry data measured for 3 in pyridine solution (Figure 2) showed the

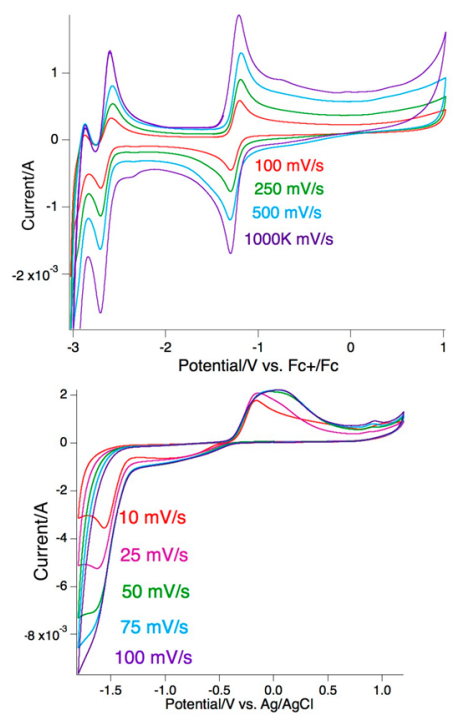

Figure 2. Cyclic voltammetry data recorded for $4 \mathrm{mM}$ solutions of $\left[\mathrm{K}(2.2 .2\right.$.cryptand) $]\left[\mathrm{UO}_{2}\right.$ (dpaea) $]$ (3) in $0.1 \mathrm{M}\left[\mathrm{Bu}_{4} \mathrm{~N}\right]\left[\mathrm{PF}_{6}\right]$ pyridine solution at $100-1000 \mathrm{~K} \mathrm{mV} / \mathrm{s}$ scan rate $\mathrm{Cp}_{2} \mathrm{Fe} / \mathrm{Cp}_{2} \mathrm{Fe}^{+}$ corrected (top) and in aqueous HEPES solutions $(\mathrm{pH}=7)$ at $10-100$ $\mathrm{mV} / \mathrm{s}$ scan rates vs $\mathrm{Ag} / \mathrm{AgCl}$ (bottom).

presence of two reversible redox events at $E_{1 / 2}=-1.25 \mathrm{~V}$ and at $E_{1 / 2}=-2.65 \mathrm{~V}$ that were assigned to the $\mathrm{U}(\mathrm{VI}) / \mathrm{U}(\mathrm{V})$ and $\mathrm{U}(\mathrm{V}) / \mathrm{U}(\mathrm{IV})$ couples respectively (no redox event is observed in the voltammogram of $\left.\mathrm{K}_{2} \mathrm{dpaea}\right)$. The measured redox potential for the $\mathrm{U}(\mathrm{VI}) / \mathrm{U}(\mathrm{V})$ couple falls in the range $(-0.93$ $-+1.82 \mathrm{~V})$ of those reported for other uranyl(V) complexes in organic media. ${ }^{8 \mathrm{~d}, \mathrm{f}, 16}$ The voltammogram measured in $0.02 \mathrm{M}$ HEPES buffered water solutions $(\mathrm{pH}=7)$ at a glassy carbon working electrode shows a significant shift of the $\mathrm{U}(\mathrm{VI}) / \mathrm{U}(\mathrm{V})$ redox potentials with the $\mathrm{U}(\mathrm{V}) / \mathrm{U}(\mathrm{VI})$ oxidation event found at $E=-0.16-0.00 \mathrm{~V}$ vs $\mathrm{Ag} / \mathrm{AgCl}$, and the $\mathrm{U}(\mathrm{VI}) / \mathrm{U}(\mathrm{V})$ reduction at $E=-1.56$ to $-1.65 \mathrm{~V}$ vs $\mathrm{Ag} / \mathrm{AgCl}$ depending on the scan speed. These values are very similar to those previously reported for the uranyl(V)-carbonato complex $\left(\left[\mathrm{UO}_{2}\left(\mathrm{CO}_{3}\right)_{3}\right]^{5-}\right)$ in $\mathrm{Na}_{2} \mathrm{CO}_{3}$ at $\mathrm{pH}=12$ and a glassy carbon electrode (oxidation peak at $0-0.25 \mathrm{~V}$ and reduction peak at -1.5 to $-1.7 \mathrm{~V}) .^{6 \text { a,d }}$ The $\mathrm{U}(\mathrm{V}) / \mathrm{U}(\mathrm{IV})$ redox event is not observable in water solution.

Similar to what was reported for the $\operatorname{uranyl}(\mathrm{V})$-carbonate complex the $\mathrm{U}(\mathrm{VI}) / \mathrm{U}(\mathrm{V})$ couple is electrochemically irreversible in water solution. The different electrochemical behavior of the $\mathrm{U}(\mathrm{VI}) / \mathrm{U}(\mathrm{V})$ couple in water compared to pyridine suggests that its irreversibility in water could be related to water binding and/or proton exchange reactions.

In conclusion, we have identified a polydentate ligand that allows the stabilization of $\operatorname{uranyl}(\mathrm{V})$ in water solution in the $\mathrm{pH}$ range 7-10 and we have isolated and fully characterized the first uranyl(V) complex that is stable in water at neutral $\mathrm{pH}$. At lower $\mathrm{pH}$ values, the complex is protonated and readily disproportionates affording U(IV) and uranyl(VI) species. These studies indicate that uranyl(V) can be stabilized in water solution in the presence of polycarboxylate ligands and that its presence in the environment is not necessarily limited to concentrated carbonate solutions. The isolation of such a stable system provides a valuable tool for investigating the mechanism of biotic and abiotic reduction of uranyl species in the environmental conditions.

\section{ASSOCIATED CONTENT}

\section{S Supporting Information}

The Supporting Information is available free of charge on the ACS Publications website at DOI: 10.1021/jacs.8b07885.

Experimental procedures, spectral data (PDF)

Crystallographic information for $\mathrm{C}_{16} \mathrm{H}_{15} \mathrm{~N}_{3} \mathrm{O}_{6} \mathrm{U}$ (CIF) Crystallographic information for $\mathrm{C}_{16} \mathrm{H}_{15} \mathrm{D}_{2} \mathrm{~N}_{3} \mathrm{O}_{7} \mathrm{U}$, $4\left(\mathrm{D}_{2} \mathrm{O}\right)(\mathrm{CIF})$

Crystallographic information for $\mathrm{C}_{16} \mathrm{H}_{15} \mathrm{~N}_{3} \mathrm{O}_{6} \mathrm{U}$, $\mathrm{C}_{20} \mathrm{H}_{30} \mathrm{Co}, 4\left(\mathrm{C}_{5} \mathrm{H}_{5} \mathrm{~N}\right)$ ( CIF)

Crystallographic information for $\mathrm{C}_{34} \mathrm{H}_{51} \mathrm{KN}_{5} \mathrm{O}_{12} \mathrm{U}$ (CIF)

Crystallographic information for $\mathrm{C}_{32} \mathrm{H}_{30} \mathrm{~N}_{6} \mathrm{O}_{8} \mathrm{U}$ (CIF)

\section{AUTHOR INFORMATION}

\section{Corresponding Author}

*marinella.mazzanti@epfl.ch

ORCID

Marinella Mazzanti: 0000-0002-3427-008X

Notes

The authors declare no competing financial interest.

\section{ACKNOWLEDGMENTS}

We thank F. Fadaei Tirani for her contribution to the X-ray single crystal structure data collection and analyses, A. Sienkiewicz for EPR data collection, F. Le Formal for the help with electrochemistry. This work was supported by the Ecole Polytechnique Fédérale de Lausanne (EPFL) and by the Swiss National Science Foundation grant (number CR23I2_16645).

\section{REFERENCES}

(1) (a) Su, J.; Windorff, C. J.; Batista, E. R.; Evans, W. J.; Gaunt, A. J.; Janicke, M. T.; Kozimor, S. A.; Scott, B. L.; Woen, D. H.; Yang, P. J. Am. Chem. Soc. 2018, 140, 7425-7428. (b) Windorff, C. J.; Chen, G. P.; Cross, J. N.; Evans, W. J.; Furche, F.; Gaunt, A. J.; Janicke, M. T.; Kozimor, S. A.; Scott, B. L. J. Am. Chem. Soc. 2017, 139, 39703973. (c) Deblonde, G. J. P.; Sturzbecher-Hoehne, M.; Rupert, P. B.; An, D. D.; Illy, M. C.; Ralston, C. Y.; Brabec, J.; de Jong, W. A.; Strong, R. K.; Abergel, R. J. Nat. Chem. 2017, 9, 843-849. (d) La Pierre, H. S.; Scheurer, A.; Heinemann, F. W.; Hieringer, W.; Meyer, K. Angew. Chem., Int. Ed. 2014, 53, 7158-7162. (e) Jones, M. B.; Gaunt, A. J. Chem. Rev. 2013, 113, 1137-1198. (f) Natrajan, L.; Burdet, F.; Pecaut, J.; Mazzanti, M. J. Am. Chem. Soc. 2006, 128, $7152-7153$.

(2) Morss, L. R.; Edelstein, N. M.; Fuger, J. The Chemistry of the Actinide and Transactinide Elements; Springer: Dordrecht, 2006.

(3) (a) Natrajan, L. S.; Swinburne, A. N.; Andrews, M. B.; Randall, S.; Heath, S. L. Coord. Chem. Rev. 2014, 266, 171-193. (b) Arnold, P. L.; Love, J. B.; Patel, D. Coord. Chem. Rev. 2009, 253, 1973-1978.

(c) Renshaw, J. C.; Butchins, L. J. C.; Livens, F. R.; May, I.; Charnock, J. M.; Lloyd, J. R. Environ. Sci. Technol. 2005, 39, 5657-5660. (d) Ilton, E. S.; Haiduc, A.; Cahill, C. L.; Felmy, A. R. Inorg. Chem. 2005, 44, 2986-2988. (e) Yuan, K.; Ilton, E. S.; Antonio, M. R.; Li, Z.; Cook, P. J.; Becker, U. Environ. Sci. Technol. 2015, 49, 6206-6213.

(f) Burns, P. C.; Finch, R. J. Am. Mineral. 1999, 84, 1456-1460. 
(g) Bell, N. L.; Shaw, B.; Arnold, P. L.; Love, J. B. J. Am. Chem. Soc. 2018, 140, 3378-3384.

(4) (a) Ilton, E. S.; Pacheco, J. S. L.; Bargar, J. R.; Shi, Z.; Liu, J.; Kovarik, L.; Engelhard, M. H.; Felmy, A. R. Environ. Sci. Technol. 2012, 46, 9428-9436. (b) Ilton, E. S.; Boily, J.-F.; Buck, E. C.; Skomurski, F. N.; Rosso, K. M.; Cahill, C. L.; Bargar, J. R.; Felmy, A. R. Environ. Sci. Technol. 2010, 44, 170-176. (c) Roberts, H. E.; Morris, K.; Law, G. T. W.; Mosselmans, J. F. W.; Bots, P.; Kvashnina, K.; Shaw, S. Environ. Sci. Technol. Lett. 2017, 4, 421-426.

(5) (a) Selbin, J.; Ortego, J. D. Chem. Rev. 1969, 69, 657-671. (b) Kraus, K. A.; Nelson, F.; Johnson, G. L. J. Am. Chem. Soc. 1949, 71, 2510-2517. (c) Ekstrom, A. Inorg. Chem. 1974, 13, 2237-2241.

(6) (a) Docrat, T. I.; Mosselmans, J. F. W.; Charnock, J. M.; Whiteley, M. W.; Collison, D.; Livens, F. R.; Jones, C.; Edmiston, M. J. Inorg. Chem. 1999, 38, 1879-1882. (b) Wester, D. W.; Sullivan, J. C. Inorg. Chem. 1980, 19, 2838-2840. (c) Mizuoka, K.; Grenthe, I.; Ikeda, Y. Inorg. Chem. 2005, 44, 4472-4474. (d) Ikeda, A.; Hennig, C.; Tsushima, S.; Takao, K.; Ikeda, Y.; Scheinost, A. C.; Bernhard, G. Inorg. Chem. 2007, 46, 4212-4219.

(7) Berthet, J. C.; Siffredi, G.; Thuery, P.; Ephritikhine, M. Chem. Commun. 2006, 3184-3186.

(8) (a) Arnold, P. L.; Patel, D.; Wilson, C.; Love, J. B. Nature 2008, 451, 315-318. (b) Takao, K.; Tsushima, S.; Takao, S.; Scheinost, A. C.; Bernhard, G.; Ikeda, Y.; Hennig, C. Inorg. Chem. 2009, 48, 96029604. (c) Horeglad, P.; Nocton, G.; Filinchuk, Y.; Pecaut, J.; Mazzanti, M. Chem. Commun. 2009, 1843-1845. (d) Nocton, G.; Horeglad, P.; Vetere, V.; Pecaut, J.; Dubois, L.; Maldivi, P.; Edelstein, N. M.; Mazzanti, M. J. Am. Chem. Soc. 2010, 132, 495-508. (e) Mougel, V.; Pecaut, J.; Mazzanti, M. Chem. Commun. 2012, 48, 868-870. (f) Hayton, T. W.; Wu, G. J. Am. Chem. Soc. 2008, 130, 2005-2014. (g) Hayton, T. W.; Wu, G. Inorg. Chem. 2008, 47, 74157423. (h) Arnold, P. L.; Cowie, B. E.; Suvova, M.; Zegke, M.; Magnani, N.; Colineau, E.; Griveau, J. C.; Caciuffo, R.; Love, J. B. Angew. Chem., Int. Ed. 2017, 56, 10775-10779. (i) Arnold, P. L.; Hollis, E.; Nichol, G. S.; Love, J. B.; Griveau, J. C.; Caciuffo, R.; Magnani, N.; Maron, L.; Castro, L.; Yahia, A.; Odoh, S. O.; Schreckenbach, G. J. Am. Chem. Soc. 2013, 135, 3841-3854. (j) Arnold, P. L.; Pecharman, A. F.; Hollis, E.; Yahia, A.; Maron, L.; Parsons, S.; Love, J. B. Nat. Chem. 2010, 2, 1056-1061. (k) Mougel, V.; Horeglad, P.; Nocton, G.; Pecaut, J.; Mazzanti, M. Chem. - Eur. J. 2010, 16, 14365-14377. (1) Chatelain, L.; Mougel, V.; Pecaut, J.; Mazzanti, M. Chem. Sci. 2012, 3, 1075-1079. (m) Mougel, V.; Horeglad, P.; Nocton, G.; Pecaut, J.; Mazzanti, M. Angew. Chem., Int. Ed. 2009, 48, 8477-8480. (n) Nocton, G.; Horeglad, P.; Pécaut, J.; Mazzanti, M. J. Am. Chem. Soc. 2008, 130, 16633-16645. (o) Burdet, F.; Pecaut, J.; Mazzanti, M. J. Am. Chem. Soc. 2006, 128, $16512-16513$.

(9) (a) Mougel, V.; Chatelain, L.; Pecaut, J.; Caciuffo, R.; Colineau, E.; Griveau, J. C.; Mazzanti, M. Nat. Chem. 2012, 4, 1011-1017. (b) Chatelain, L.; Tuna, F.; Pecaut, J.; Mazzanti, M. J. Chem. Soc.Dalton Trans. 2017, 46, 5498-5502. (c) Chatelain, L.; Walsh, J. P. S.; Pecaut, J.; Tuna, F.; Mazzanti, M. Angew. Chem., Int. Ed. 2014, 53, 13434-13438. (d) Chatelain, L.; Tuna, F.; Pecaut, J.; Mazzanti, M. Chem. Commun. 2015, 51, 11309-11312. (e) Chatelain, L.; Pecaut, J.; Tuna, F.; Mazzanti, M. Chem. - Eur. J. 2015, 21, 18038-18042. (f) Mougel, V.; Chatelain, L.; Hermle, J.; Caciuffo, R.; Colineau, E.; Tuna, F.; Magnani, N.; de Geyer, A.; Pecaut, J.; Mazzanti, M. Angew. Chem., Int. Ed. 2014, 53, 819-823. (g) Schnaars, D. D.; Wu, G.; Hayton, T. W. J. Am. Chem. Soc. 2009, 131, 17532-17533. (h) Hayton, T. W.; Wu, G. Inorg. Chem. 2009, 48, 3065-3072. (i) Pankhurst, J. R.; Bell, N. L.; Zegke, M.; Platts, L. N.; Lamfsus, C. A.; Maron, L.; Natrajan, L. S.; Sproules, S.; Arnold, P. L.; Love, J. B. Chem. Sci. 2017, 8, 108-116. (j) Kiernicki, J. J.; Zeller, M.; Bart, S. C. Angew. Chem., Int. Ed. 2017, 56, 1097-1100.

(10) (a) Regueiro-Figueroa, M.; Rolla, G. A.; Esteban-Gomez, D.; de Blas, A.; Rodriguez-Blas, T.; Botta, M.; Platas-Iglesias, C. Chem. - Eur. J. 2014, 20, 17300-17305. (b) Pellissier, A.; Bretonniere, Y.; Chatterton, N.; Pecaut, J.; Delangle, P.; Mazzanti, M. Inorg. Chem. 2007, 46, 3714-3725.
(11) Hawkins, C. A.; Bustillos, C. G.; Copping, R.; Scott, B. L.; May, I.; Nilsson, M. Chem. Commun. 2014, 50, 8670-8673.

(12) Hayton, T. W. J. Chem. Soc.-Dalton Trans. 2018, 47, 10031009.

(13) (a) Szigethy, G.; Raymond, K. N. J. Am. Chem. Soc. 2011, 133, 7942-7956. (b) Szigethy, G.; Raymond, K. N. Inorg. Chem. 2010, 49, $6755-6765$.

(14) (a) Sundararajan, M.; Campbell, A. J.; Hillier, I. H. J. Phys. Chem. A 2008, 112, 4451-4457. (b) Steele, H.; Taylor, R. J. Inorg. Chem. 2007, 46, 6311-6318. (c) Collins, R. N.; Rosso, K. M. J. Phys. Chem. A 2017, 121, 6603-6613.

(15) Evans, D. F. J. Chem. Soc. 1959, 2003-2005.

(16) Kim, S. Y.; Asakura, T.; Morita, Y.; Ikeda, Y. J. Alloys Compd. 2006, 408, 1291-1295. 